\title{
Enzymatic activity in braúna seeds subjected to thermal stress
}

\section{Atividade enzimática em sementes de braúna submetidas ao estresse térmico}

\author{
Glauciana da Mata Ataíde ${ }^{I}$ Eduardo Euclydes de Lima e Borges ${ }^{\text {II }}$ \\ Andressa Vasconcelos Flores ${ }^{\text {III }}$
}

\section{ABSTRACT}

To occur seed germination distinct hydrolytic enzymes work together, enabling primary root protrusion. The objective of this study was to investigate changes in the activities of $\alpha$-amylase, $\beta$-amylase, and glucose-6-phosphate dehydrogenase (G6PdH) during germination of Melanoxylon brauna Schott. seeds under thermal stress. To this end, seeds of this species were germinated under constant temperature $\left(10,25,30\right.$ or $\left.40^{\circ} \mathrm{C}\right)$ and samples were collected every $24 \mathrm{~h}$ during a 96-h period, in which the activity of the enzymes were evaluated. At 25 and $30^{\circ} \mathrm{C}$, optimal temperatures for the germination of the species, the activities of $\alpha$-amylase, $\beta$-amylase, and $G 6 P d H$ increased with seed imbibitions. At 10 and $40^{\circ} \mathrm{C}$, enzyme activities decreased, impairing the germination process.

Key words: $\alpha$-amylase, $\beta$-amylase, glucose-6-phosphate dehydrogenase, Melanoxylon brauna.

\section{RESUMO}

Para que ocorra a germinação das sementes, enzimas hidroliticas distintas atuam em conjunto, permitindo a protrusão da raiz primária. $O$ objetivo neste trabalho foi investigar as alterações nas atividades das enzimas $\alpha$-amilase, $\beta$-amilase e glicose-6-fosfatodesidrogenase durante a germinação das sementes de Melanoxylon brauna Schott, submetidas ao estresse térmico. Para tanto, sementes da espécie foram submetidas ao teste de germinação em temperaturas constantes de $10,25,30$ e $40^{\circ} \mathrm{C}$, sendo retiradas amostras de sementes a cada 24 horas, durante o periodo de 96 horas, nas quais foi avaliada a atividade das enzimas. Nas temperaturas 25 e $30^{\circ} \mathrm{C}$, consideradas ótimas para a germinação da espécie, as atividades das enzimas $\alpha$-amilase, $\beta$-amilase e glicose-6-fosfato-desidrogenase aumentam com a embebição das sementes, enquanto, nas temperaturas 10 e $40^{\circ} \mathrm{C}$, as atividades das enzimas são reduzidas, prejudicando o desenvolvimento adequado do processo germinativo.

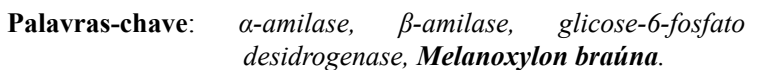

\section{INTRODUCTION}

Interest in the propagation of native forest species has been intensified in recent years. It is as a result of the need to recover degraded areas and restore the landscape, in addition to new environmental legislation requirements.

Among the species of ecological and economic importance is Melanoxylon brauna Schott. (Fabaceae - Caesalpinioideae), commonly known as brauna. This species grows in the Northeast and Southeast regions of the Atlantic Forest in Brazil (LORENZI, 2009), and is well known for the quality and durability of its wood (GONZAGA, 2006). It is currently on the "Official List of Endangered Flora of Brazil" established by Ministério do Meio Ambiente (Ministry of Environment) Normative Instruction No. 06 (MMA, 2008). Therefore, it is crucial to further investigate the propagation strategies of this species, with particular emphasis on the germination of its seeds, which do not display dormancy and germinate easily (FLORES et al., 2014).

Seed germination is a fundamental stage in the plant life cycle (MEI \& SONG, 2010) and consists of a complex and orderly set of physiological and biochemical events that result in the rupture of the integument by the primary root, which then continues to develop until a new plant is formed (BEWLEY et al., 2013).

\footnotetext{
IDepartamento de Ciências Agrárias, Universidade Federal de São João Del Rei (UFSJ), 35701-970, Sete Lagoas, MG, Brasil. E-mail: glauciana@ufsj.edu.br. Corresponding author.

IIDepartamento de Engenharia Florestal, Universidade Federal de Viçosa (UFV), Viçosa, MG, Brasil.

IIIUniversidade Federal de Santa Catarina (UFSC), Curitibanos, SC, Brasil.
} 
Among the factors affecting germination, temperature plays a key role, as it determines the capacity and rate of seed germination (ZAMITH et al., 2013), assists in overcoming primary and/ or secondary dormancy (MONDONI et al., 2012), affects the speed of water absorption by the seeds (ATAÍDE et al., 2014), and controls the rate of the biochemical reactions that determine the entire process (MATOS et al., 2014).

For primary root protrusion to occur, various hydrolytic enzymes must participate, many of which are de novo transcribed and synthesized (BEWLEY et al., 2013). Among these enzymes are the amylases, which are activated in the embryo at the start of hydration (LEE \& KIM, 2000) and constitute a group of enzymes responsible for breaking down starch molecules into various products, including dextrins and progressively smaller glucose polymers (SINGH \& KAYASTHA, 2014). The $\alpha$ and $\beta$-amylase enzymes are involved in the main breakdown of carbohydrates used during respiration, specifically starch; this activity is critical to provide the embryo with energy and a carbon skeleton (SFAXI-BOUSBIH et al., 2010).

Another key enzyme, glucose-6-phosphate dehydrogenase $(\mathrm{G} 6 \mathrm{PdH})$, acts on the alternative pentose monophosphate pathway and is responsible for maintaining appropriate levels of NADPH in the cells (ASAI et al., 2011). Due to its involvement in the seeds' respiratory process, it may act as an indicator of declining physiological quality in stressful environments, and in particular, be associated with damage to cell membrane structure (KEVERS et al., 2004).

Considering that little is known about the enzymatic activity of native forest species' seeds during germination, and that this process is influenced by environmental factors, the objective of this study was to investigate the changes in $\alpha$-amylase, $\beta$-amylase, and G6PdH activities in M. brauna seeds subjected to temperature stress during germination.

\section{MATERIALS AND METHODS}

This study was conducted at the Forest Seed Laboratory of the Department of Forestry at the Federal University of Viçosa (FUV), from October 2012 to February 2013. The M. brauna seeds were collected from the Leopoldina region in Minas Gerais in September2012, and were then processed, selected, packed into 2-L impermeable fiber drums, and stored in a cold chamber at $5^{\circ} \mathrm{C}$ and $60 \% \mathrm{RH}$ for a month.

The M. brauna seeds were germinated in Petri dishes containing two sheets of Germi test paper moistened with distilled water, and provided continuous lighting by four $40 \mathrm{~W}$ daylight fluorescent lamps at $10,25,30$ or $40^{\circ} \mathrm{C}$ constant temperature for 10 days (FLORES et al., 2014). Seeds were considered to have germinated when primary root protrusion was observed; the average germination percentage was then calculated. The germination rate (GR) was calculated according to the formula provided by MAGUIRE (1962). For the germination test, five replicates of 20 seeds each were used for each temperature.

At each interval and aforementioned temperature, the $\alpha$-amylase, $\beta$-amylase and G6PdH activities were evaluated. Enzymes $\alpha$ - and $\beta$-amylase were quantified by the method described by BERNFELD (1955), using starch as the substrate. The determination of G6PdH activity was performed according to the methodology described by DUKE et al. (1977). The protein concentration was measured according to Bradford (1976), using a standard curve constructed with bovine serum albumin (BSA). Enzymatic assays were performed in five replicates of $1.0 \mathrm{~g}$ of cotyledons each for $\alpha$ - and $\beta$-amylase, and $0.1 \mathrm{~g}$ of cotyledons and embryonic axis for G6PdH.

The experiment was conducted in a completely randomized design, subjected to an analysis of variance (ANOVA), and the germination and GR average values compared by Tukey's test at $5 \%$ probability level. The activities of the enzymes were evaluated by up to third degree polynomial regression, selected according to the significance of the equation by F-test $(p<0.05)$ and coefficient of determination $\left(\mathrm{R}^{2}\right)$. The statistical program used for all analyses was Statistica 8.0 (StatSoft, Inc.).

\section{RESULTS AND DISCUSSION}

The highest germination percentages of M. brauna seeds (93 and 98\%) were observed at 25 and $30^{\circ} \mathrm{C}$, respectively. These percentages showed no significant difference from each other and were statistically higher than germination at 10 and $40^{\circ} \mathrm{C}$, at which both average germination percentages were $5 \%$ (Figure $1 \mathrm{~A}$ ). However, at $30^{\circ} \mathrm{C}$ the germination rate was greater than at $25^{\circ} \mathrm{C}$, displaying statistically different averages (Figure 1B).

The specific activity of the $\alpha$-amylase enzyme tended to increase during the first 24 hours of germination at $10^{\circ} \mathrm{C}$, and then remained constant until the end of the evaluation period (96h), as shown in figure $2 \mathrm{~A}$. At 25 and $30^{\circ} \mathrm{C}$, the enzyme activity continued to increase throughout the germination process, peaking at $96 \mathrm{~h}$ of imbibitions (Figures 2B 

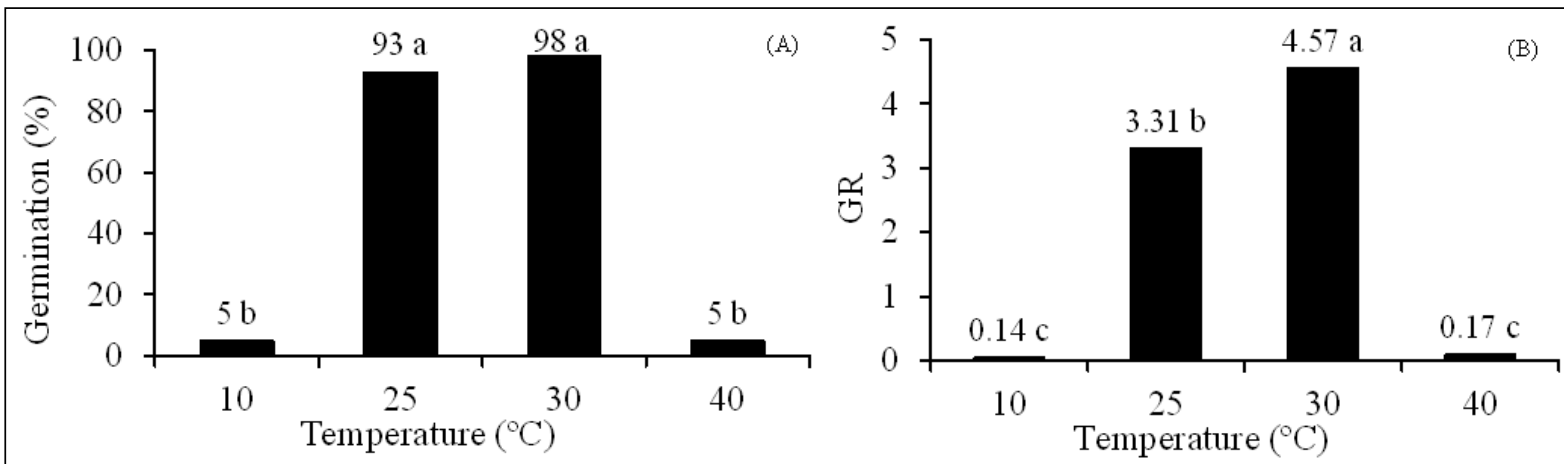

Figure 1 - Germination (A) and germination rate (GR) (B) of Melanoxylon brauna seeds at 10, 25, 30 and $40^{\circ} \mathrm{C}$. Bars labeled the same letter do not differ by Tukey's test $(\mathrm{P}=0.05)$.

and $2 \mathrm{C})$. These values represent a 77.1 and $62.7 \%$ increase when compared to the total initial value of the enzyme $\left(0.01475 \mathrm{mg}\right.$ glucose $\cdot \mathrm{mL}^{-1} \cdot \mathrm{mg}^{-1}$ protein $)$. During seed germination at $40^{\circ} \mathrm{C}$, the specific activity of $\alpha$-amylase increased in the first $48 \mathrm{~h}$, and had stabilized by $72 \mathrm{~h}$, with an average of 0.0186 $\mathrm{mg}$ glucose $\cdot \mathrm{mL}^{-1} \cdot \mathrm{mg}^{-1}$ protein at 72 and $96 \mathrm{~h}$ of imbibitions (Figure 2D).

Conversely, the $\beta$-amylase enzyme activity measured at time zero was $0.01018 \mathrm{mg}$ glucose $\cdot \mathrm{mL}^{-1} \cdot \mathrm{mg}^{-1}$ protein, which increased during seed germination at 10,25 and $30^{\circ} \mathrm{C}$, reaching $0.01899,0.01956$, and $0.01955 \mathrm{mg}$ glucose $\cdot \mathrm{mL}^{-1} \cdot \mathrm{mg}^{-1}$ protein after $96 \mathrm{~h}$ of imbibitions (Figure 2A-C). At $40^{\circ} \mathrm{C}$, the enzyme activity remained stable throughout the observation period, such that at 10 and $40^{\circ} \mathrm{C}$, which are above and below the optimum range for germination of M. brauna seeds, respectively, the enzyme activity was negatively influenced (Figure 2D).

In suitable physiological conditions, the enzymes involved in germination are synthesized
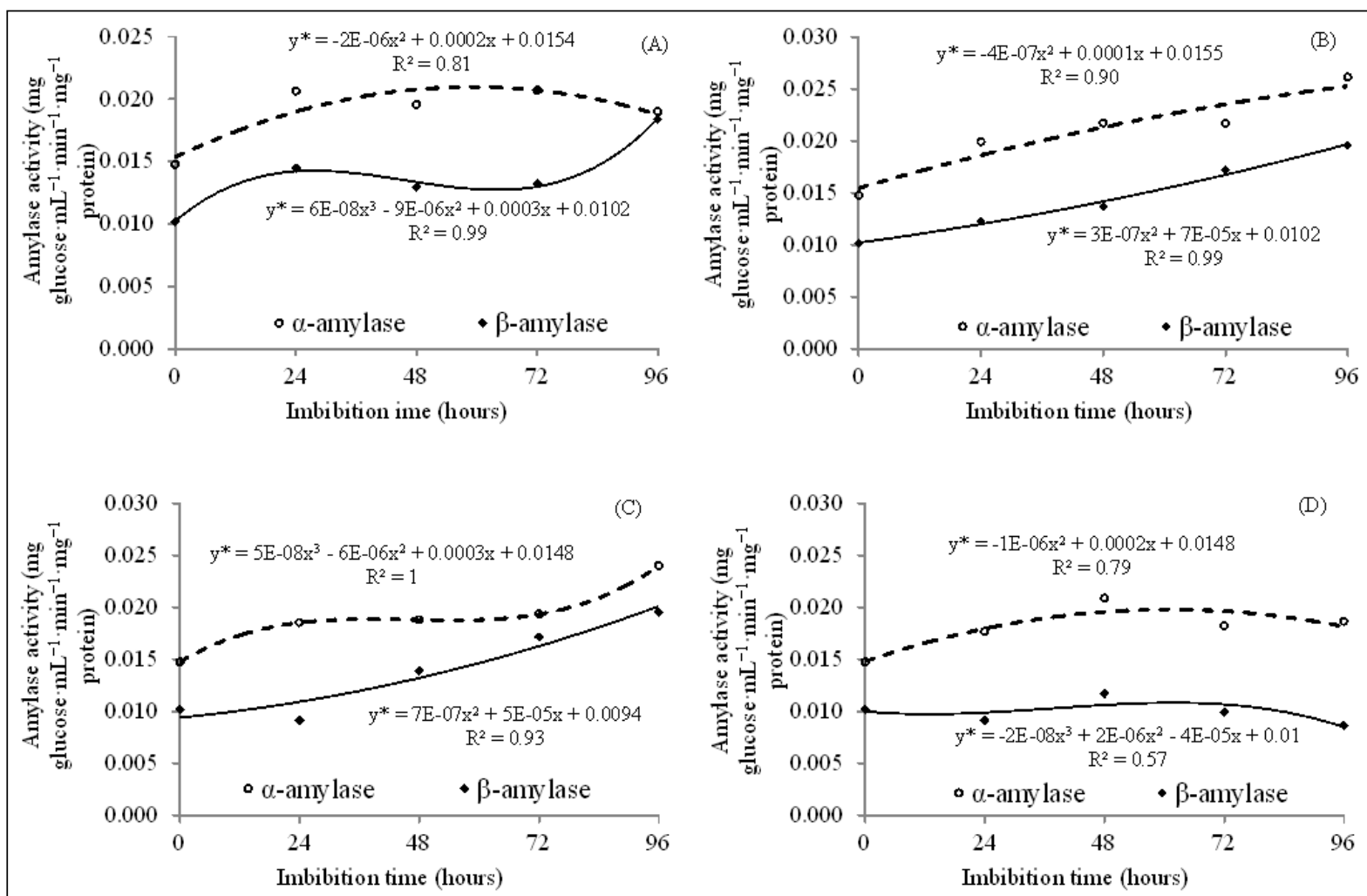

Figure 2 - $\alpha$-amylase and $\beta$ enzyme activity $\left(\mathrm{mg}\right.$ glucose $\cdot \mathrm{mL}^{-1} \cdot \mathrm{min}^{-1} \cdot \mathrm{mg}^{-1}$ protein) in Melanoxylon brauna seeds during germination at 10 (A), $25(\mathrm{~B}), 30(\mathrm{C})$ and $40^{\circ} \mathrm{C}(\mathrm{D}) . *$ - significant by F-test $(\mathrm{P}=0.05)$. 
and activated as the hydration of the seeds progresses; during this process, the amylases hydrolytically cleave starch molecules. The enzyme $\alpha$-amylase begins the mobilization of reserves, hydrolyzing the internal $\alpha-1,4$ bonds of linear or branched glycans of the amylopectin component of starch molecules (SMITH et al., 2005). The $\beta$-amylase acts after the $\alpha$-amylase, breaking the alternate $1,4-\alpha$-Dglucosidiclinkages from the non-reducing end of starchinto maltose, which will be then transported into the cytosol and hydrolyzed by $\alpha$-glucosidase into glucose (VALERIO et al., 2011).

Increases in amylase activity during germination have been observed in Aniba rosaeodora (LIMA et al., 2008), Hordeum vulgare (SANTOS et al., 2010), Sorghum vulgare (RAIMI et al., 2012), and Cajanus cajan (LAURA et al., 2013). In Triticum aestivum seeds, the production of $\alpha$-amylase was reduced during germination at temperatures lower than the optimum species (FLEMING et al., 1960); such behavior is related to plant metabolic response to low temperatures.

It was reported, during the germination of Sorghum bicolor seeds, (TAWABA et al., 2013) that from $24^{\circ} \mathrm{C}$, a $4-8^{\circ} \mathrm{C}$ rise in the temperature was sufficient to reduce the synthesis of $\beta$-amylase. Diminishing enzyme synthesis is consistent with lower maltose and maltotriose release at high temperatures. Furthermore, KAPLAN \& GUY (2004) reported lower amylase activity to be associated with increased germination temperature, when it exceeded the optimum temperature range for seed germination. In this study, the average activity of G6PdH at time zero in M. brauna seeds was 0.10000 and $0.10770 \mu \mathrm{mol} \cdot \mathrm{min}^{-1} \cdot \mathrm{mg}^{-1}$ in the embryonic axis and cotyledons respectively (Figure 3 ). At 25 and $30^{\circ} \mathrm{C}$, the enzyme activity tended to stabilize in the cotyledons and to increase in the embryonic axis. The increase was most accentuated after $84 \mathrm{~h}$ of imbibitions at $30^{\circ} \mathrm{C}$, a period in which root protrusion was also observed at this temperature, displaying activity equivalent to $333.36 \%$ of initial levels.

At $25^{\circ} \mathrm{C}, \mathrm{G} 6 \mathrm{PdH}$ activity during the $96 \mathrm{~h}$ imbibitions period increased $79.99 \%$ compared to the initial activity, reaching values of 0.18622 $\mu \mathrm{mol} \cdot \mathrm{min}^{-1} \cdot \mathrm{mg}^{-1}$. This contrasts with the enzyme activity at $10^{\circ} \mathrm{C}$, which was steady in the embryonic axis and increased in the first $24 \mathrm{~h}$ of germination, followed by slow and continuous decrease in the cotyledons, where it reached $0.07979 \mu \mathrm{mol} \cdot \mathrm{min}^{-}$
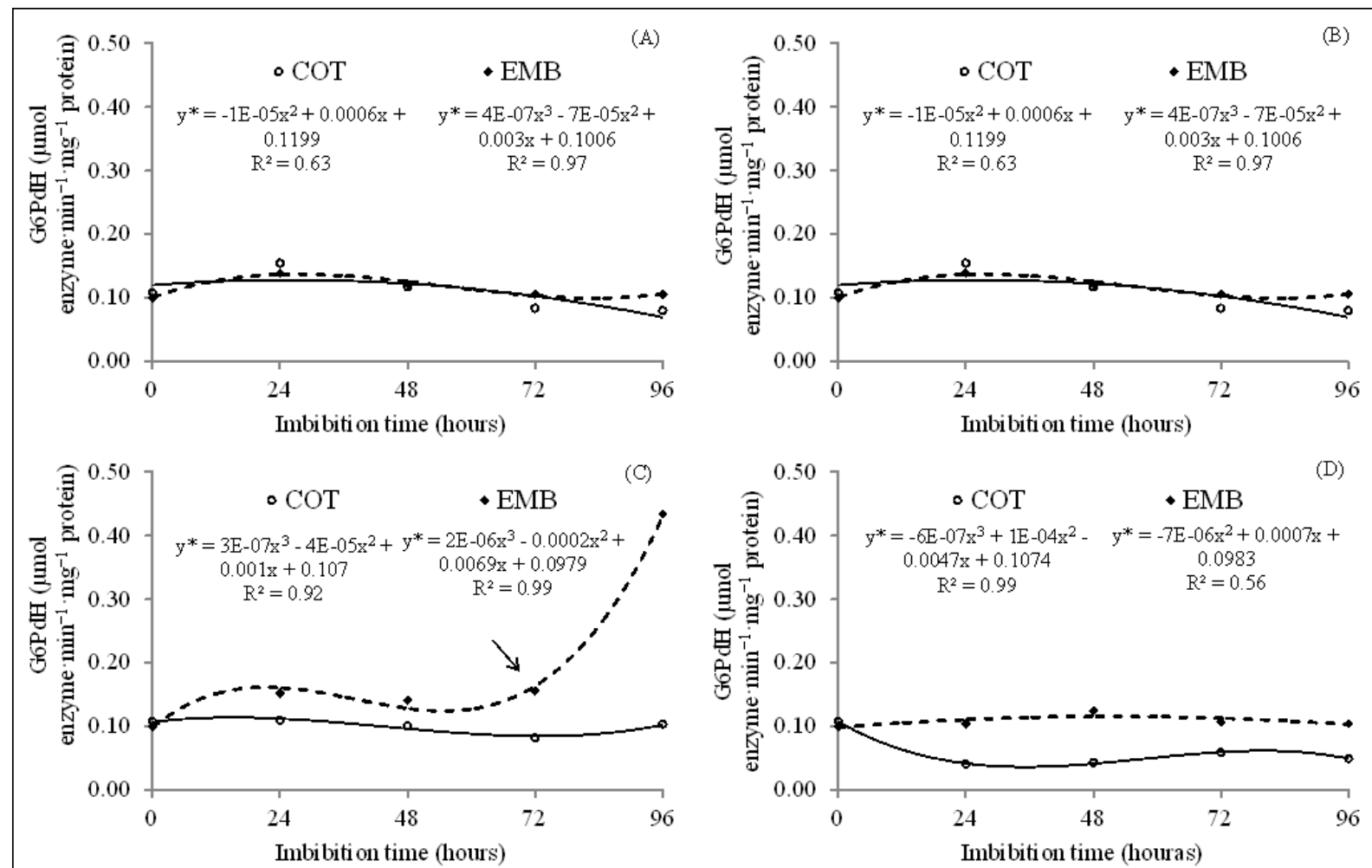

Figure 3 - Glucose 6-phosphate dehydrogenase $(\mathrm{G} 6 \mathrm{PdH})$ enzyme activity $\left(\mu \mathrm{mol} \cdot \mathrm{min}^{-1} \cdot \mathrm{mg}^{-1}\right.$ protein) in embryonic axes $(\mathrm{EMB})$ and cotyledons (COT) of Melanoxylon brauna seeds during germination at 10 (A), 25 (B), 30 (C) and $40^{\circ} \mathrm{C}$ (D). *- significant by F-test $(\mathrm{P}=0.05)$. 
${ }^{1} \cdot \mathrm{mg}^{-1}$ at the end of imbibitions (Figure $3 \mathrm{~A}$ ). At $40^{\circ} \mathrm{C}$, $\mathrm{G} 6 \mathrm{PdH}$ activity was also stable in the embryonic axis, whereas it decreased in the cotyledons from the beginning of the evaluation period, being observed at $0.04412 \mu \mathrm{mol} \cdot \mathrm{min}^{-1} \cdot \mathrm{mg}^{-1}$ activity after $12 \mathrm{~h}$. Then it remained practically the same during the imbibitions of the seeds, and it was $0.04495 \mu \mathrm{mol} \cdot \mathrm{min}^{-1} \cdot \mathrm{mg}^{-1}$ at $96 \mathrm{~h}$ of imbibitions (Figure 3D).

The G6PdH enzyme is involved in the cellular respiration process, specifically in the alternative pentose monophosphate pathway, and is responsible for maintaining proper levels of NADPH in the cells (SHAN-ZHI et al., 2005). In response to some kind of stress, for instance, low or high temperature $\left(10\right.$ and $\left.40^{\circ} \mathrm{C}\right)$, the reduction in seed germination may be associated with lower enzyme activity (Figure 1B), indicating a possible decline in internal metabolic functions. A similar decline in physiological quality of Oryza sativa seeds was associated with low respiratory rate a and reduction in $\mathrm{G} 6 \mathrm{PdH}$ activity; this reduction corresponded to the exposure of the seeds to temperatures above $25^{\circ} \mathrm{C}$ (MARINI et al., 2013).

The association of G6PdH activity with the loss of quality was also found in seeds of Glycine max (MUNIZ et al., 2007). Because it is the first NADPHgenerating enzyme in the pentose phosphate pathway (WAKAO et al., 2008), G6PdH-deficient cells are highly sensitive to oxidative stress, in contrast to those expressing appropriate levels of enzyme activity (LIU et al., 2007). The fact that G6PdH is a regulatory enzyme in this oxidative pathway (TAIZ \& ZEIGER, 2013) suggests that the stress caused by the temperatures during seed germination of $\boldsymbol{M}$. brauna likely resulted in less available energy for biosynthetic processes during germination, owing to lower enzyme activity.

In contrast, the increase in $\mathrm{G} 6 \mathrm{PdH}$ activity during the post-germination period at $30^{\circ} \mathrm{C}$ expressed the efficiency of the respiratory activity during this period, when the new seedlings presented higher respiratory rates than seeds submitted to imbibitions. According to BEWLEY et al. (2013), respiration increases linearly as more substrates are available for seeds, justifying the large oxygen consumption rates and mobilization of reserves in the post-germination period.

\section{CONCLUSION}

At 25 and $30^{\circ} \mathrm{C}$, the $\alpha$-amylase, $\beta$-amylase, and G6PdHactivities increase with the imbibitions time of Melanoxylon brauna seeds. The $\alpha$-amylase, $\beta$-amylase, and $\mathrm{G} 6 \mathrm{PdH}$ activities at 10 and $40^{\circ} \mathrm{C}$ are lower compared to 25 and $30^{\circ} \mathrm{C}$.

\section{REFERENCES}

ASAI, S. et al. A plastidic glucose-6-phosphate dehydrogenase is responsible for hypersensitive response cell death and reactive oxygen species production. Journal of General Plant Pathology, v.77, n.3, p.152-162, 2011. Available from: <http://dx.doi. org/10.1007/s10327-011-0304-3>. Accessed: Nov. 20, 2013. doi: 10.1007/s10327-011-0304-3.

ATAÍDE, G.M. et al. Imbibition of jacaranda-da-bahia seeds. Pesquisa Florestal Brasileira, v.34, n.78, p.133139, 2014. Available from: <http://dx.doi.org/10.4336/2014. pfb.34.78.520>. Accessed: Dec. 15, 2013. doi: 10.4336/2014. pfb.34.78.520.

BERNFELD, P. Amylases, $\alpha$ and $\beta$. Methods in Enzymology, v.1, n.40, p.149-151, 1955. Available from: <http://www. garfield.library.upenn.edu/classics1986/A1986E108100001.pdf>. Accessed: Dec. 15, 2013.

BEWLEY, J.D. et al. Seeds: physiology of development, germination and dormancy. Nova York: Springer, 2013. 392p.

BRADFORD, M.M. A rapid and sensitive method for the quantitation of microgram quantities of protein utilizing the principle of protein-dye binding. Analytical Biochemistry, v.72, n.1-2, p.248-254, 1976. Available from: <http://www.ciens.ucv. ve:8080/generador/sites/lab-bioq-gen/archivos/Bradford $\% 20$ 1976.pdf $>$. Accessed: Nov. 10, 2013.

DUKE, S.H. et al. Low temperature effects on soybean (Glycine $\boldsymbol{m a x}$ [L.] Merr. cv. 'Wells') mitochondrial respiration and several dehydrogenases during imbibition and germination. Plant Physiology, v.60, n.1, p.716-722, 1977. Available from: <http:// www.plantphysiol.org/content/60/5/716.full.pdf + html $>$. Accessed: Dec. 15, 2013. doi: 10.1104/pp.60.5.716.

FLEMING, J.R. et al. Effect of malting procedure and wheat storage conditions on alpha-amylase and protease activities. Malting Procedure vs. Enzyme Activity, v.37, n.2, p.363-370, 1960. Available from: $<$ http://www.aaccnet.org/publications/cc/backissues/1960/documents/ chem37_363.pdf>.Accessed: Dec. 09, 2014.

FLORES, A.V. et al. Germination of Melanoxylon brauna Schott seeds in different temperatures. Revista Árvore, v.38, n.6, p.11471154, 2014. Available from: <http://www.scielo.br/pdf/rarv/v38n6/ a19v38n6.pdf>. Accessed: Aug. 17, 2015.

GONZAGA, A.L. Madeira: uso e conservação. Brasília: IPHAN/ Monumenta, 2006. 246p. Available from: $<$ http://www.monumenta. gov.br/upload/Caderno\%20Madeiraweb_1173383037.pdf $>$. Accessed: Feb. 20, 2014.

KAPLAN, F.; GUY, C.L. $\beta$-Amylase induction and the protective role of maltose during temperature shock. Plant Physiology, v.135, n.3, p.1674-1684, 2004. Available from: <http://dx.doi. org/10.1104/pp.104.040808>. Accessed: Jun. 12, 2013. doi: $10.1104 /$ pp. 104.040808

KEVERS, C. et al. Hyperhydricity of micropropagated shoots: a typically stress-induced change of physiological state. Plant Cell, Tissue and Org Culture, v.77, n.2, p.181191, 2004. Available from: <http://dx.doi.org/10.1023/ B:TICU.0000016825.18930.e4>. Accessed: Dec. 10, 2013. doi: 10.1023/B:TICU.0000016825.18930.e4. 
LAURA, J.S. et al. Toxicity impacts of sewage effluent on the amylase activity of pigeon pea (Cajanus cajan L.) plant. International Journal of Development Research, v.3, n.4, p.1820,2013. Available from: <http://www.journalijdr.com/sites/default/ files/Download\%201001-022.pdf>. Accessed: Dec. 09, 2014.

LEE, S.S.; KIM, J.H. Total sugars, $\alpha$-amylase activity and germination after priming of normal and aged rice seeds. Korean Journal of Science, v.45, n.2, p.108-111, 2000.Available from: <http://www. dbpia.co.kr/Journal/ArticleDetail/910921>. Accessed: Dec. 10, 2014.

LIMA, R.B.S. et al. Primary metabolite mobilization during germination in rosewood (Aniba rosaeodora ducke) seeds. Revista Árvore, v.32, n.1, p.19-25, 2008. Available from: $<$ http://www.scielo. br/scielo.php?pid=S0100-67622008000100003\&script=sci_arttext $>$. Accessed: Nov. 13, 2014. doi: 10.1590/S0100-67622008000100003.

LIU, Y. et al. Glucose-6-Phosphate dehydrogenase plays a pivotal role in nitric oxide-involved defense against oxidative stress under salt stress in red kidney bean roots. Plant Cell Physiology, v.48, n.3, p.511-522, 2007. Available from: <http://dx.doi.org/10.1093/ pcp/pcm020>. Accessed: Jun. 06, 2013. doi: 10.1093/pcp/pcm020.

LORENZI, H. Árvores brasileiras: manual de identificação e cultivo de plantas arbóreas nativas do Brasil. Nova Odessa: Plantarum, 2009. 384p.

MAGUIRE, J.D. Speed of germination: aid in selection and evaluation for seedling emergence and vigor. Crop Science, v.2, n.2, p.176-177, 1962.

MARINI, P. et al. Indicativos da perda de qualidade de sementes de arroz sob diferentes temperaturas através da atividade enzimática e respiratória. Interciência, v.38, n.1, p.54-59, 2013. Available from: <http://www.redalyc.org/pdf/339/33926506002. pdf>. Accessed: Dec. 09, 2014.

MATOS, A.C.B. et al. Production of reactive oxygen species in Dalbergia nigra seeds under thermal stress. Journal of Seed Science, v.36, n.3, p.282-289, 2014. Available from: <http:// dx.doi.org/10.1590/2317-1545v36n3973>. Accessed: Dec. 09, 2014. doi: $10.1590 / 2317-1545 v 36 n 3973$.

MEI, Y.; SONG, S. Response to temperature stress of reactive oxygen species scavenging enzymes in the cross-tolerance of barley seed germination. Journal of Zhejiang University Science, v.11, n.12, p.965-972, 2010. Available from: <http:// dx.doi.org/10.1631/jzus.B1000147>. Accessed: Jun. 06, 2013. doi: 10.1631/jzus.B1000147.

MMA (MINISTÉRIO DO MEIO AMBIENTE). Instrução Normativa n.6 de 23 de setembro de 2008. Lista Oficial das Espécies da Flora Brasileira Ameaçadas de Extinção. Available from: <http://www.mma.gov.br/estruturas/ascom_boletins/ arquivos/83_19092008034949.pdf>. Accessed: May 01, 2013.

MONDONI, A. et al. Temperature controls seed germination and dormancy in the European woodland herbaceous perennial Erythronium dens-canis (Liliaceae). Plant Biology, v.14, n.3, p.475-480, 2012. Available from: <http://dx.doi.org/10.1 111/j.1438-8677.2011.00517.x>. Accessed: Jun. 06, 2013. doi: 10.1111/j.1438-8677.2011.00517.x.

MUNIZ, F.R. et al. Physiological quality of corn, bean, soybean and lettuce seeds in the presence of sedge extract. Revista Brasileira de Sementes, v.29, n.2, p.195-204, 2007. Available from: <http:// www.scielo.br/pdf/rbs/v29n2/v29n2a26.pdf $>$. Accessed: Dec. 10, 2014. doi: 10.1590/S0101-31222007000200026.

RAIMI, O.G. et al. Effect of germination time on fat and protein contents, and $\alpha$-amylase activity of Guinea Corn (Sorghum vulgare). Pakistan Journal of Food Sciences, v.22, n.2, p.86-89, 2012. Available from: $<$ http://psfst.com/ jpd fstr/6b4994daf2db 193d800804085325c481.pdf>. Accessed: Dec. 09, 2014.

SANTOS, I.J. et al. Expression of alpha and beta amylase during the germination of barley. Revista Brasileira de Produtos Agroindustriais, v.12, n.1, p.67-73, 2010. Available from: $<$ http://www.deag.ufcg.edu.br/rbpa/rev121/Art1219.pdf $>$. Accessed: Dec. 09, 2014

SFAXI-BOUSBIH, A. et al. Copper affects the cotyledonary carbohydrate status during the germination of bean seed. Biological Trace Element Research, v.137, n.1, p.110-116, 2010. Available from: <http://dx.doi.org/ 10.1007/s12011-009-8556-x>. Accessed: Jul. 14, 2014. doi: 10.1007/s12011-009-8556-x.

SHAN-ZHI, L. et al. Role of glucose-6-phosphate dehydrogenase in freezing-induced freezing resistance of Populus suaveolens. Journal of Plant Physiology and Molecular Biology, v.31, n.1, p.34-40, 2005. Retrieved from: $<$ http://www.ncbi.nlm.nih.gov/ pubmed/15692176>. Accessed: Jul. 14, 2014.

SINGH, K.; KAYASTHA, A.M. A-amylase from wheat (Triticum aestivum) seeds: its purification, biochemical attributes and active site studies. Food Chemistry, v.1, n.162, p.1-9, 2014. Available from: $<$ http://dx.doi.org/10.1016/j.foodchem.2014.04.043>.Accessed: Jul. 13, 2014. doi: 10.1016/j.foodchem.2014.04.043.

SMITH, A.M. et al. Starch degradation. Annual Review of Plant Biology, v.56, n.1, p.73-98, 2005. Available from: <http://dx.doi. org/10.1146/annurev.arplant.56.032604.144257>. Accessed: Dec. 10, 2014. doi: 10.1146/annurev.arplant.56.032604.144257.

TAIZ, L; ZEIGER, E. Fisiologia vegetal. 4. ed. Porto Alegre: ARTMED. 2013. 719p.

TAWABA, J.B. et al. Modelling the $\beta$-amylase activity during red sorghum malting when Bacillus subtilis is used to control mould growth. Journal of Cereal Science, v.57, n.1, p.115-119, 2013. Available from: $<$ http://dx.doi.org/doi:10.1016/j.jcs.2012.10.004>. Accessed: Jul. 13, 2014. doi: 10.1016/j.jcs.2012.10.004.

VALERIO, C. et al. Thioredoxin-regulated $\beta$-amylase (BAM1) triggers diurnal starch degradation in guard cells, and in mesophyll cells under osmotic stress. Journal of Experimental Botany, v.62, n.2, p. 545-555, 2011. Available from: <http://dx.doi.org/10.1093/ jxb/erq288>. Accessed: Jul. 13, 2014. doi: 10.1093/jxb/erq288.

WAKAO, S. et al. Functional analyses of cytosolic glucose6-phosphate dehydrogenases and their contribution to seed oil accumulation in Arabidopsis. Plant Physiology, v.146, n.1, p.277-288, 2008. Available from: <http://dx.doi.org/ 10.1104/pp.107.108423>. Accessed: Dec. 09, 2014. doi: 10.1104/pp.107.108423.

ZAMITH, L.R. et al. The effect of temperature on the germination of Melocactus violaceus Pfeiff. (Cactaceae), a threatened species in restinga sandy coastal plain of Brazil. Anais da Academia Brasileira de Ciências, v.85, n.2, p.615-622, 2013. Available from: $\quad<$ http://dx.doi.org/10.1590/S0001-37652013000200010>. Accessed: Jul. 13, 2014. doi: 10.1590/S0001-37652013000200010. 